UDC 368.9:369.06

DOI: https://doi.org/10.32782/2520-2200/2019-5-34

\author{
Voronkova Olena \\ University of State Fiscal Service of Ukraine
}

\author{
Воронкова О.М. \\ доктор економічних наук, профресор, \\ профресор кафедри фрінансових ринків \\ Університету державної фріскальної служби України
}

\title{
DEVELOPMENT PRIORITIES OF MEDICAL INSURANCE IN UKRAINE
}

\section{ПРІОРИТЕТИ РОЗВИТКУ МЕДИЧНОГО СТРАХУВАННЯ В УКРАЇНІ}

Actual problems of medical insurance in Ukraine are investigated in the study. Strengths and weaknesses, opportunities and threats of the domestic medical insurance market are analyzed. The influence of the newest factors on the state of the Ukrainian medical insurance market is described. The priority directions of the medical insurance development in current national realities are substantiated. Based on the analysis of the problematic aspects of the functioning of the medical insurance system in Ukraine, the priority directions of its development in the current national realities are substantiated. There are improvement and modernization of products of voluntary medical insurance; gradual and balanced implementation of compulsory medical insurance; to attract more insurants through effective marketing; to increase transparency in the medical insurance market and to develop its infrastructure, stimulating the investment activity of insurance companies by improving the regulatory framework. As a result of the implementation of these measures, citizens will be able to receive high-quality medical care, the government will receive an effect of the budget expenditures reduction, and insurance companies providing medical insurance will be able to increase the efficiency of their activities.

Key words: medical insurance, insurance market, compulsory medical insurance, voluntary medical insurance, insurance companies, insurance services, insurer, insurant.

В статье исследованы актуальные проблемы медицинского страхования в Украине. Проанализированы сильные и слабые стороны, возможности и угрозы отечественного рынка медицинского страхования. Охарактеризовано влияние современных фракторов на состояние украинского рынка медицинского страхования. Обоснованы приоритетные направления развития медицинского страхования в современных украинских реалиях. На основе анализа проблемных аспектов функционирования системы медицинского страхования в Украине обоснованы приоритетные направления ее развития. Среди них совершенствование и модернизация продуктов добровольного медицинского страхования; постепенное и сбалансированное внедрение обязательного медицинского страхования; привлечение страхователей с помощью эффективного маркетинга; повышение прозрачности рынка медицинского страхования и развитие его инфраструктуры путем стимулирования инвестиционной активности страховых компаний на основе совершенствования нормативно-правовой базы. В результате реализации этих мер граждане смогут получать качественную медицинскую помощь, правительство - эфффект от сокращения бюджетных расходов, а страховые компании, предоставляющие медицинское страхование, - повышение эфффективности своей деятельности.

Ключевые слова: медицинское страхование, страховой рынок, обязательное медицинское страхование, добровольное медицинское страхование, страховые компании, страховые услуги, страховщик, страхователь.

Створення стабільної та ефективної системи охорони здоров'я, що забезпечує громадянам кваліфріковану медичну допомогу та підтримує здоров'я людей, є одним із ключових суспільних завдань для нашої країни. Сьогодні в Україні медична сфера переживає кризу, спричинену не лише недостатнім фрінансуванням, а й неефективним його використанням. Медичне страхування в Україні має високий потенціал розвитку, але відсутні дієві механізми його реалізації. Мета даної роботи - проаналізувати проблемні аспекти медичного страхування в Україні та обгрунтувати пріоритети його розвитку. Під час дослідження використовувались загальнонаукові та спеціальні методи. Актуальні проблеми медичного страхування в українських реаліях досліджено за допомогою системного та порівняльного аналізу, а також спостереження та аналогії. Використовуючи метод SWOT-аналізу, проаналізовано сильні та слабкі сторони, а також можливості та загрози 
ринку медичного страхування в Україні. Методи логічного узагальнення та екстраполяції використовувались при обґрунтуванні пріоритетів розвитку медичного страхування в Україні. У роботі проведено дослідження актуальних проблем медичного страхування в Україні. Проаналізовано сильні та слабкі сторони, можливості і загрози вітчизняного ринку медичного страхування. Охарактеризовано вплив сучасних чинників на стан українського ринку медичного страхування. На основі аналізу проблемних аспектів функціонування системи медичного страхування в Україні обґрунтовано пріоритетні напрями їі розвитку. Серед них модернізація продуктів добровільного медичного страхування; поступове і збалансоване впровадження обов'язкового медичного страхування; залучення страхувальників за допомогою ефективного маркетингу; підвищення прозорості ринку медичного страхування і розвиток його інфрраструктури шляхом стимулювання інвестиційної активності страхових компаній на основі вдосконалення нормативно-правової бази. В результаті реалізації цих заходів громадяни зможуть отримати якісну медичну допомогу, уряд скорочення бюджетних витрат, а страхові компанії, що надають медичне страхування, - підвищення ефективності своєї діяльності. Оцінка ефективності запропонованих заходів є перспективним напрямком подальших досліджень у страховій сфрері. Результати дослідження можуть бути використані для підготовки заходів державної фінансової політики, розробки змін та доповнень до законодавства України, що регулює сферу страхування, підготовки державних програм розвитку фрінансових та страхових ринків.

Ключові слова: медичне страхування, страховий ринок, обов'язкове медичне страхування, добровільне медичне страхування, страхові компанії, страхові послуги, страховик, страхувальник.

Formulation of the problem. Formation of the stable and effective health care system providing citizens with qualified medical assistance and supporting people's health is one of the key public tasks in our country. Nowadays in Ukraine the medical sphere is experiencing a crisis caused not only by inadequate funding, but also ineffective use of it. Medical insurance in Ukraine has a high potential for development, but there are no effective mechanisms for its implementation. The problems of the health insurance system improvement in general, the effectiveness of voluntary medical insurance increase and compulsory medical insurance implementation are being updated in modern Ukrainian realities.

Nowadays in the world there are three basic models of the medical sphere funding: state, budgetary, private. Despite the different forms of financial providing health care systems in developed countries provide effective medical care, high quality health care and access to a wide range of people. The world experience in health insurance systems reformation states that the financial mechanism of healthcare can be improved both within budgetary financing and health insurance.

A lot of key health issues are being solved in the area of compulsory medical insurance, the introduction of which has encountered in Ukraine with many problems of an objective and subjective nature. In our country only voluntary forms of medical insurance operates, and the sphere of its functioning is also characterized by many problematic aspects. An actual analysis of these problems in the field of medical insurance will enable to determine the key priorities of its development in current national realities. It determines the actuality, scientific and practical importance of this work.
Analysis of recent research and publications. Key issues of the formation and development of the medical insurance industry have been researched by such Ukrainian and foreign scientists in particular Buchkevich M., Vnukova N., Gamankova O., Danilchenko L., Drobot Ya., Koval O., Manzhosova O., Nagaichuk N., Petrushka O., Prikazjuk N., Fedorova N., Shevchuk Yu., Chernov S., Chumachenko I.

Among recent researches on medical insurance issues, devoted to the prospects and priority directions of its development, it is worth noting the works of Bihovchenko V., Ivanoyuk O. and Gorodnichoy Yu.[1]; Koval O. and Nochvaj O. [2]; Kostenko T., Stokolyuk V. and Zavoloki L. [3] etc.

However, highly dynamic and high-risk Ukrainian realities have a significant impact on the functioning of the insurance market in general and its medical insurance segment in particular. It necessitates constant updating of determinants of their actual state and development taking into account the influence of the newest factors.

Consequently, in spite of the significant work of these specialists, researches of the latest trends in the field of medical insurance in particular in problems identifying and the priorities of its development justification in the current Ukrainian realities does not disappear.

The aim of the study is to analyze the actual problems of medical insurance in Ukraine and to substantiate the priorities of its development.

Presentation of the main research results. Medical insurance has acquired a modern look not so long ago although it has developed for several centuries. The legal definition of "medical insurance" in Ukraine is not defined, and therefore it is the subject of many discussions. Taking into account the available findings of the relevant spe- 
cialists and the results of our own research, we propose to define medical insurance as a combination of insurance forms that provide for the insurer's obligations to make insurance payments for partial or full compensation of expenses for medical aid in the insured event, determined by the current legislation or insurance contract, due to the formation of special funds.

Medical insurance may be compulsory and voluntary. Compulsory medical insurance is one of the most important elements of the social protection system of the population in terms of health care and receiving of necessary medical aid in case of illness. Voluntary medical insurance is a commercial type of insurance that is based not on the principle of insurance solidarity but on the principle of equivalence. Voluntary medical insurance gives citizens the opportunity to receive additional medical services beyond the guarantee of compulsory medical insurance programs.

Currently only voluntary medical insurance is in Ukraine. The active process of transferring the Ukrainian health care system to the insurance model began in 2017. On 30.11.2016 the Cabinet of Ministers of Ukraine approved the concept of the health care system reformation [4]. The main principle of the funding system change according to the approved concept was the payment by the state of a guaranteed package of medical services to every citizen. It proposed a model of the national health insurance system, which included three main directions: 1) fund raising through general taxation to the state budget; 2) creation of a national insurer - National Health Service; 3 ) payment for each medical service.

It should also be noted that the leaders of the insurance market in insurance payments include medical insurance and insurance of medical expenses. Payments for medical insurance in 2018 are UAH 1002.6 million (2017-UAH1571.6 million), and for insurance of medical expenses are UAH 311.5 million (2017 - UAH 261.4 million) [5]. By types of insurance in the structure of net insurance premiums, medical insurance has a share of about $10 \%$, in the structure of net insurance compensations - about $17 \%$, and it is despite the fact that its volumes are constantly growing. The domestic insurance market is still being developed and improved. There are many issues that point to the need to change priorities in the main areas of health care organization.

First of all, insufficient financing of medicine, imperfect legislative framework, outdated requirements for the training of medical professionals, unsuccessful strategy of social and economic policy, unequal conditions for the implementation of medical activities for various subjects are is among these problematic issues.
The legislation of Ukraine stipulates that budget expenditures for the development of the healthcare sector should amount to not less than $10 \%$ of the country's GDP. However, this norm is not implemented in Ukraine, and expenditures are only $6-7 \%$ of GDP $[6, p .77]$. As practice experience shows, the government provides medicine for its citizens at the minimum level. Ukrainians pay their own funds for necessary medicines, medical services, examinations, etc. In Germany the number of health care facilities is significantly lower than in Ukraine, and the expenses of patients are several times higher. Due to the outdated approach and technology, in-patient treatment in our country is twice as long as in many European countries.

In most cases the healthcare industry problems are argued for inadequate funding. However, foreign experience shows that the increase in expenditures on health care is not enough, structural changes are needed in this area as well. For example, Russia made medical insurance compulsory, but the structural part of the transformations remained unnoticed, so the positive result is almost imperceptible.

Medical insurance is a specific type of insurance activity. Therefore, it is not easy for insurers to combine it with other types of insurance. Despite the positive trends in voluntary medical insurance there are many problems in this sector.

Firstly, insurance companies generally do not want to provide medical insurance services, because according to their own research the level of insurance claims in this area of insurance is at least $45-60 \%$, which is economically unjustified, unprofitable, and cost-effective for the insurer [7, p. 623]. In addition citizens themselves are uncommonly purchasing voluntary medical insurance policies because of their high prices.

One more problematic issue is the structure of the client base. Nowadays provision of insurance services for medical insurance to individuals is not profitable. There are few physical persons among existing and/or potential clients, and they try to get the most benefit from the insurance contract at the time of the conclusion of an agreement they have had potential health problems. Legal enterprises insure basically not less several hundred employees and choose average cost or expensive insurance products with a wide range of services, and insurance cases compared with the number of insured are rare, so they are safe and convenient to insure. It is thanks to corporate insurance the voluntary medical insurance market annually has a stable growth.

The next factor, also of a financial character, concerns the cooperation of insurers with health care institutions. In order to minimize costs and maximize profits, they seek to work with state 
medical institutions, which usually do not have highly qualified staff, effective drugs, advanced equipment and qualitative diagnostics. It is clear that any person with negative experience of treatment in such institution will not conclude the contract of voluntary medical insurance. In general medical insurance around the world is quite expensive, only for quite rich citizens. They will want to buy such a policy only if they are confident in the quality of the health service and the reputation of the healthcare institution.

It is also difficult for insurers to control the quality of services rendered to insured in the insured event and to improve the quality of service at public health facilities. The sphere of state medicine, namely the inadequate level of healthcare infrastructure, constrains the development of voluntary medical insurance. It makes insurers to deal with private clinics.

An important issue is the reliability of Ukrainian insurance companies providing medical insurance services and their enhancement. It is necessary to maintain a competitive environment among insurers, which will result in the improvement of the offered insurance products while simultaneously setting their optimal price.

Regarding reliability all insurance companies guarantee the provision of medical care anywhere in the territory of Ukraine when selling a medical insurance product, although in practice few of them are actually ready to meet the terms of the contract in remote areas.

It should also be noted the low level of insurance culture of Ukrainian society. The problem of fraud both insurers and insurants is actual. Insurers try to refuse payment for the treatment of their clients in the insurance event; insurants try to deceive the price of medical services for more compensation.

Also, the problem of choosing a well-reputed medical institution and high-quality medical care is still topical. Among the institutions with which an insurer cooperates and to which insurant has the right to apply for the terms of the insurance contract, it is necessary to choose independently and in a random way.

Among the theoretical and normative problems it is necessary to highlight the problems of the interpretation and standardization of key medical terms, in particular: medical services, medical care, medical insurance, insurance medicine, etc.

There are also general problems, but no less significant, as they affect the development and conditions of the functioning of the medical insurance market. They are national problems: political, economic and social instability, low living standards, distrust of non-state financial institutions, imperfect tax policy, etc.
In addition to the above, the regulatory framework remains unregulated, fundamental laws of Ukraine regarding the rights of the patient and health care workers, health care institutions, standardization in the sphere of health care, and the guaranteed basic unpaid medical aid are not adopted. Since important laws have not been adopted, there is no single approach to the form of ownership of insurance funds - they can be public, private, mixed, or even co-existing with one another. The draft Law of Ukraine "On Compulsory State Social Medical Insurance" is under development.

However, if the introduction of compulsory medical insurance in Ukraine will be without appropriate preparatory changes, taxes on personal incomes in particular salary will increase. It will cause the transition of payers to the shadow sector. Also, the introduction of compulsory medical insurance is impossible without organizational infrastructure to provide health insurance services, sufficient experience and level of knowledge of medical professionals, modern and advanced information technologies [8]. That's why Ukraine is extremely interested in the intensive development of voluntary medical insurance, which is currently poorly developed in comparison with other countries as shown in Table 1.

The data of Table 1 shows that in developed insurance markets medical insurance is one of the most effective sectors, unlike Ukraine. Insurers in developed countries stimulate the demand for insurance services for medical insurance, increase the cost of medical care, thereby increasing the amount of medical insurance premiums.

Ukrainian insurance companies are also trying to develop and apply new ways of strategic management, improve the quality of health insurance services and their own competitiveness. The reason for this is the new information flows, customer demand for quality of medical services, technology development in the diagnostic and therapeutic areas.

An important strategic management tool that can assess the opportunities, threats, strengths and weaknesses of a particular medical insurance company, and the medical insurance market in general, is the SWOT analysis. This analysis shows a comprehensive picture of the functioning of the medical insurance market, predicts its directions for development in the future and ways to increase the efficiency of companies providing medical insurance services. Basing on the available results of relevant studies [10; 11] and taking into account the current domestic realities of the insurance market, the matrix of SWOT analysis of the medical insurance market in Ukraine was constructed (Table 2). 
Table 1

The prevalence of voluntary medical insurance in Ukraine and some developed countries

\begin{tabular}{|l|c|c|c|}
\hline \multicolumn{1}{|c|}{ Country } & $\begin{array}{c}\text { The share of the } \\
\text { population in the VMI, \% }\end{array}$ & VMI, \% of GDP & $\begin{array}{c}\text { VMI in expenditures } \\
\text { on health care, \% }\end{array}$ \\
\hline Ukraine & 1,00 & 0,01 & 0,25 \\
\hline Germany & 10,00 & 1,34 & 12,50 \\
\hline Canada & 70,00 & 1,03 & 11,20 \\
\hline USA & 70,10 & 4,59 & 34,80 \\
\hline France & 86,00 & 1,20 & 12,80 \\
\hline
\end{tabular}

Source: given on [9]

Table 2

Matrix of SWOT analysis of the Ukrainian medical insurance market

\begin{tabular}{|c|c|c|}
\hline & Opportunities & Threats \\
\hline & $\begin{array}{l}\text { introduction of compulsory health } \\
\text { insurance; } \\
\text { development of specific insurance } \\
\text { mediation; } \\
\text { growth of insurance investments; } \\
\text { high level of education of the } \\
\text { population; } \\
\text { orientation towards the European } \\
\text { lifestyle; } \\
\text { increase of corporate culture in } \\
\text { the aspect of health insurance. }\end{array}$ & $\begin{array}{l}\text { political, social and economic } \\
\text { instability; } \\
\text { high inflation and rise of services } \\
\text { prices; } \\
\text { unfair competition; } \\
\text { shadow calculations with } \\
\text { doctors; } \\
\text { low staff level; } \\
\text { constant reduction of } \\
\text { population; } \\
\text { low insurance culture. }\end{array}$ \\
\hline Strengths & Strengths and opportunities & Strengths and threats \\
\hline $\begin{array}{l}\text { fast development; } \\
\text { raise of the capitalization level of } \\
\text { the insurance market; } \\
\text { creation of assistant centers; } \\
\text { a wide range of medical } \\
\text { insurance programs; } \\
\text { flexible price policy; } \\
\text { compulsory medical insurance } \\
\text { of foreign citizens who are in } \\
\text { Ukraine on a temporary basis. }\end{array}$ & $\begin{array}{l}\text { improvement and modernization } \\
\text { of medical insurance programs; } \\
\text { gradual and weighted } \\
\text { introduction of compulsory } \\
\text { medical insurance; } \\
\text { improvement of financial } \\
\text { instruments for placement of } \\
\text { insurance investments; } \\
\text { formation of demand for } \\
\text { insurance products; } \\
\text { increase the number of clients. }\end{array}$ & $\begin{array}{l}\text { exclusion of certain risks from } \\
\text { insurance policies; } \\
\text { lobby the interests of individual } \\
\text { insurers in the competent } \\
\text { authorities; } \\
\text { creation of competitive } \\
\text { insurance products; } \\
\text { professional development of } \\
\text { staff; } \\
\text { formation of an insurance } \\
\text { culture of the population; } \\
\text { indexation of premiums and } \\
\text { payments. }\end{array}$ \\
\hline Weaknesses & Weaknesses and opportu & Weaknesses and threats \\
\hline $\begin{array}{l}\text { imperfection of the legislative } \\
\text { framework; } \\
\text { high level of market } \\
\text { concentration; } \\
\text { limited investment opportunities; } \\
\text { low level of competitiveness of } \\
\text { national insurers; } \\
\text { absence of a state strategy for } \\
\text { the development of medical } \\
\text { insurance. }\end{array}$ & $\begin{array}{l}\text { improvement of the legal base of } \\
\text { insurance; } \\
\text { creation of a highly competitive } \\
\text { and transparent insurance } \\
\text { environment; } \\
\text { strengthening of the } \\
\text { competitiveness of domestic } \\
\text { insurers; } \\
\text { development of effective } \\
\text { marketing strategies; } \\
\text { development of the insurance } \\
\text { market infrastructure. }\end{array}$ & $\begin{array}{l}\text { manipulation of the provisions } \\
\text { of legislation, unjustified use of } \\
\text { preferential regimes; } \\
\text { introduction of compulsory } \\
\text { medical insurance; } \\
\text { creation of marketing } \\
\text { departments in insurance } \\
\text { companies; } \\
\text { introduction of risk management } \\
\text { in insurance activity. }\end{array}$ \\
\hline
\end{tabular}

Source: built by author using [5; 10; 11]

The SWOT matrix focuses on the following priority measures: improvement and modernization of voluntary medical insurance products, gradual and well-meaningful introduction of compulsory medical insurance; attracting more insurants through effective marketing strategies, improvement of the regulatory framework in terms of increase of the medical insurance market transparency and development of its infrastructure, as well as stimulation of the investment activity of insurance companies, in particular combining insurance investments with insurance 
protection through construction of new financial instruments.

As a result of the implementation of such measures, citizens will be able to receive affordable and quality medical care, the shadow component in the healthcare system will be significantly reduced, corresponding expenditures from the budget will be reduced and the effectiveness of the life insurance companies will increase.

Conclusions and perspectives for further research in this field. Medical insurance is a combination of forms of insurance to provide citizens with guarantees for medical care in the insurance case at the expense of accumulated insurance funds. According to sources of funding, medical insurance is divided into compulsory medical insurance based on public funding principles, and voluntary, based on personal contributions of individuals, the sizes of which depend on the level of medical risk. The volume of health care within the scope of voluntary insurance depends on the chosen insurance program.

The experience of developed countries confirms that the basis of insurance medicine is compulsory medical insurance. The transition to the insurance model of the health care system began in 2017 in Ukraine. This transition involves such measures: definition of the volume and structure of the state guaranteed medical services package; the transition of healthcare providers to contract services; creation of institutional and legal conditions for introduction of new methods of payment of medical services to suppliers; practical use of new methods of primary care financing using the standard per capita; creation of e-Health tools for collection and processing medical, financial and managerial data; updating of the program classification of budget expenditures on health care. However, the introduction of compulsory medical insurance in our country has not yet been completed.

Nowadays only voluntary medical insurance is in Ukraine. We support the idea that an effective medical insurance system should provide for three determinants: a minimum size budget fund that provides free medical care for all citizens without exception; compulsory medical insurance covering basic medical services; voluntary medical insurance that covers additional medical services. In addition, Ukraine should take into account its own social features, trends in social and economic development and advanced world experience to develop an effective mechanism for the introduction of compulsory medical insurance.

The analysis of the results of the research of Ukrainian specialists in the field of medical insurance allowed to systematize the main proposals for its prospective improvement in Ukraine and to conclude that they have general nature as a rule. The main of these proposals is to develop a national strategy for the development of the insurance market; improvement of the domestic insurance law bringing it to European standards; amending the draft law on compulsory medical insurance with its subsequent adoption; effective state regulation of the insurance market and increase of trust in insurance companies; popularization of insurance among the population; the adoption of a positive world experience, etc. [1;2; 7].

Specific proposals are in particular to expand the range and quality assurance of medical insurance services, to train medical and insurance professionals, and to create a competitive mixed medical insurance system that would ensure the inflow of foreign investment in the medical sector and insurance [3, pp. 724-725].

Supporting the above-mentioned proposals, we consider it worthwhile to note that simultaneous implementation of them is currently impossible due to the lack of appropriate opportunities and political will, and Ukrainian society is simply unprepared to the introduction of compulsory medical insurance. Considering the limited possibilities for reforming the medical insurance and insurance industry, we consider it appropriate to determine its priority directions taking into account current national realities.

Based on the results of the analysis of the problematic aspects of the functioning of the medical insurance system in Ukraine, it is advisable to focus its development on the priority areas: improvement and modernization of existent voluntary medical insurance products, gradual and balanced introduction of compulsory medical insurance; attracting of more insurers through effective marketing, increase of transparency in the medical insurance market and development of its infrastructure, as well as stimulation of the investment activity of insurance companies improving the regulatory framework.

The improvement and modernization of existent voluntary medical insurance products in Ukrainian realities remains the key priority of the development of medical insurance. Typically, insurance companies operating in the medical insurance market have a standard list of services and can change their combination only at the request of the consumer of such services. Therefore, it is worth to pay attention to the special needs of policyholders and their ideas. To optimize the development of new generation insurance products in the field of voluntary medical insurance it is necessary to introduce individualized insurance plans that will be developed for each insurant and will contain the basic and specific characteristics 
of medical insurance: the main and additional risks, available options, the period of validity of the insurance product, the frequency of introduction insurance premiums, conditions for the implementation of insurance compensations.

As a result of the abovementioned measures citizens will be able to receive high-quality medi- cal care, the state will receive the effect of reduction of the corresponding budget expenditures, and insurance companies that provide medical insurance services will be able to increase the efficiency of their activities. Evaluation of the proposed measures effectiveness is a perspective direction for further research.

\section{References:}

1. Byhovchenko V.P., Ivanyuk O.V., Gorodnycha Yu.V. (2016). The state of health insurance in Ukraine and its priorities aries. Global and national problems of economy, no. 10, pp. 733-735.

2. Koval O.A., Nochvai O.I. (2014). Problems and perspectives of medical insurance introduction in Ukraine. Electronic scientific journal «Efektyvna ekonomika», no. 4, pp. 1-7.

3. Kostenko T.A., Stokolyuk V.V., Zavoloka L.O. (2018). State and perspectives of medical insurance development in Ukraine with consideration of foreign experience. Young Scientist, no. 5 (57), pp. 721-725.

4. On Approval of the concept of financing reform of the health care system. Order of the Cabinet of Ministers of Ukraine dated November 30, 2016. № 1013-p. URL: http://zakon.rada.gov.ua/laws/ show/1013-2016-p

5. Official site of the National Commission, which carries out state regulation in the field of financial services markets. URL:http://nfp.gov.ua

6. Fedorovych I.M. (2017). Theoretical and practical principles of realization of medical insurance in Ukraine. Scientific Bulletin of the International humanitarian university. Series: Economics and Management, no. 23(2), pp. 76-80.

7. Hrynchyshyn J.M., Prokopyuk A.V. (2017). Status and prospects of the insurance market in Ukraine. Young Scientist, no. 3 (43), pp. 622-626.

8. Homon D.O. (2014). Compalsory medical insurance as an alternative to budgetary financing of the health sector. Southern Ukrainian law magazine, no. 1, pp. 102-104.

9. Golovanova I.A., Krasnova O.I. (2015). Actual problems of development medical insurance during the period of market reformation. Economics and health Law, no. 1 (1), pp. 16-21.

10. Chumachenko I.L. (2017). Analysis of the system of medical insurance in Ukraine. Young Scientist, no. 10 (50), pp. 1096-1100.

11. Chernov S.I., Voronina O.O. (2016). Assessment of the state of health care and the level of health insurance in Kharkiv region. Social economy, no. 2, pp. 80-85. 